\section{Birlesik Dünya Arastırma Cypriot Journal of Educational BD-CENTER \\ Sciences}

Innovasyon ve Yayıneılık Merkezi
Volume 16, Issue 2, (2021) 669-685

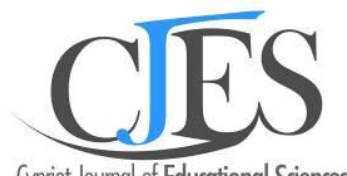

Cypriot Joumal of Educational Sciences

www.cjes.eu

\title{
The correlation between cognitive styles and written corrective feedback preferences among Iranian and Turkish EFL learners
}

Parivash Jamali Kivi ${ }^{{ }^{*}}$, Department of English Language, Islamic Azad University, Ghaemshahr branch, Ghaemshahr, Iran, https://orcid.org/0000-0002-3718-7601 Parivash.jamalikivi@yahoo.com

Ronald M. Hernández ${ }^{b}$, Unidad de Virtualización Académica, Universidad de San Martin de Porres, Perú https://orcid.org/0000-0003-1263-2454

Jorge Luis Escalante Flores ' , Universidad de Lima, Perú. https://orcid.org/0000-0002-4942-5283

Jessica Paola Palacios Garay ${ }^{d}$, Universidad Nacional Mayor de San Marcos, Perú. https://orcid.org/0000-0002-2315$\underline{1683}$

Doris Fuster-Guillén e, Universidad Nacional Mayor de San Marcos, Perú https://orcid.org/0000-0002-7889-2243

\section{Suggested Citation:}

Kivi, P. J., Hernández, R. M., Flores, J. L. E., Garay, J. P. P. \& Fuster-Guillén, D. (2021). The correlation between cognitive styles and written corrective feedback preferences among Iranian and Turkish EFL learners. Cypriot Journal of Educational Science. 16(2), 669-685. https://doi.org/10.18844/cjes.v16i2.5643

Received from November 30, 2020; revised from January 17, 2021; accepted from April 02, 2021.

C2021 Birlesik Dunya Yenilik Arastirma ve Yayincilik Merkezi. All rights reserved..

\section{Abstract}

This study aimed at finding the correlation between Iranian and Turkish EFL learners' cognitive styles and their preferences for different WCF types. Sixty out of seventy-five EFL students at the intermediate level in two contexts (Iran and Turkey) were selected through the Oxford Placement Test. There were two instruments in this research: The Learning Styles Questionnaire, and CF questionnaire. The researcher gave detailed instructions on how to complete the surveys. The findings demonstrated that there was a correlation between EFL students' cognitive styles and their WCF preferences in both Iran and Turkey contexts. The second research question results indicated that there was a relationship between learners' cognitive styles and their preferences for different types of errors to be corrected. The results of the third research question showed that the correlation between Iranian students' cognitive styles and their preferences for different CF frequencies was not significant. The last research question results showed that the correlation between Turkish students' cognitive styles and their preferences for different CF frequencies was not significant.

Keywords: Cognitive Styles - EFL Learners - Preferences - Written Corrective Feedback.

\footnotetext{
* Address of correspondence: Parivash Jamali Kivi, Department of English Language, Islamic Azad University, Ghaemshahr branch, Ghaemshahr, Iran, Email address: Parivash.jamalikivi@yahoo.com
} 
Kivi, P. J., Hernández, R. M., Flores, J. L. E., Garay, J. P. P. \& Fuster-Guillén, D. (2021). The correlation between cognitive styles and written corrective feedback preferences among Iranian and Turkish EFL learners. Cypriot Journal of Educational Science. 16(2), 669-685 https://doi.org/10.18844/cjes.v16i2.5643

\section{Introduction}

Corrective Feedback (CF) is associated with a performance form applied to enhance learner achievement (Van Beuningen et al., 2012). Hattie and Timperley (2007) defined feedback (or 'response') as "information provided by an agent regarding aspects of one's performance or understanding (p. 81)." This correction addresses a broad range of issues like text's content, organization of the writing, the vocabulary appropriateness, and so on. CF on linguistic errors as the case of the present study have received the most attention (Van Beuningen, 2010). CF can be carried out in oral or written form.

Writing skill, as one of the challenging and necessary skills in language teaching, has attracted the attention of numerous English language researchers and teachers (Shakibaei et al., 2019; Tasdemir \& Arslan, 2018). Accordingly, Tasdemir and Arslan (2018) mentioned that teachers and educational investigators attempted to find ways to help students improve L2 writing. According to Behroozi and Karimnia (2017), writing needs formal instruction to be learned, and it cannot be acquired naturally. To develop writing ability, language learners commit errors, and it needs to be corrected. In other words, one of the ways applied to assist language learners in developing their writing accuracy is the feedback provision (Amrhein \& Nassaji, 2010).

Written Corrective Feedback (WCF) has been considered as an effective way of enhancing students' writing accuracy. It is argued that Second Language (L2) learners think that teacher error correction can assist them in fostering their writing ability (Bitchener, 2008; Namaziandost et al., 2020). Besides, Carless (2006) emphasized that CF can support students to centralize their attention on the writing purpose by improving their thinking or behavior toward their work. Besides, it is also argued that numerous ESL investigators, scholars and teachers considered teacher CF is regarded as the most significant source of energy and time, and it also reduced the amount of time for designing, preparing and conducting lessons (Namaziandost et al., 2020; Yokota \& ljuin, 2009). Kellogg (2008) stated that the text might need repeatedly rewriting to reach the intended writing level. Brown (2007) claimed, "inevitably learners will make mistakes in the process of acquisition, and that process will be impeded if they do not commit errors and then benefit from various forms of feedback on those errors" (p. 216).

According to Leki (2007), feedback is seen as a necessity to enhance L2 writing. In other words, numerous researches demonstrate that $L 2$ learners have different cognitive learning styles and prefer different CF types. As Aliakbari and Qasemi (2012) suggested, the uncertainty of the CF efficacy was considered as a reason in the failure to design CF investigations and it might be related to individual differences (i.e., level of proficiency, cognitive style, aptitude, etc.) that are likely to affect how efficient CF is. Rahimi (2015) stated that cognitive factors among other individual factors appear to have a crucial role in the feedback efficacy and writing development. In the studies of Radecki and Swales (1988) and Genç (2014), results indicated that learners preferred explicit CF from teachers but other studies by Bazargani and Larsari (2013) and Hyland (2001), learners supported indirect to direct CF. They believed that indirect CF had more active role than the direct CF to play in the feedback process. On the other side, in some studies (e.g. Bitchener \& Knoch; 2010; Hashemifardnya et al., 2017; Sampson, 2012), the results demonstrated that metalinguistic CF was more efficient than other types.

Research indicates that one of the most salient factors showing differences between $L 2$ learners is their cognitive style (Hashemian \& Fadaei, 2012; Hsu \& Dwyer, 2004). Based on Chiya's view (2003), language instructors have to pay attention to learners' learning styles, "introduce, and expose them to appropriate learning strategies for successful learning" (p. 83). In addition, Brown (2007) maintained that the teaching and learning styles accommodation fosters students' momentum to attain in their academic purpose. This depends on a greater understanding of these preferences in the process of language teaching and learning. Studies by Chiya (2003) and Al Hebaishi (2012) showed the positive effect of learning styles and 
Kivi, P. J., Hernández, R. M., Flores, J. L. E., Garay, J. P. P. \& Fuster-Guillén, D. (2021). The correlation between cognitive styles and written corrective feedback preferences among Iranian and Turkish EFL learners. Cypriot Journal of Educational Science. 16(2), 669-685 https://doi.org/10.18844/cjes.v16i2.5643

strategies towards learners, numerous instructors have initiated to enhance proper teaching methods and lesson plans, and that adapt the preferences of learners. In this area, investigators also have determined that students' learning strategies selection is affected by their preferred learning styles (Hashemifardnia et al., 2018). There are also learning theories that tend to advocate the decisive role of WCF.

Interaction theories by Long (1997) and Swain (1995) support the positive role of WCF. These theories state, "L2 input must be pushed to give modified output in interactions" (Long, 1997, p. 86). McLaughlin (1990) developed the skill acquisition models in the 1980s claims that, language learning is just like the learning of cognitive skills and simple processes that can eventually lead to the development of complex behavior (Dekeyser, 2007). The socio-cultural theory by Vygotsky's (1987) states that cognitive development is based on an outcome of social interactions between people. Learning happens when a less knowledgeable person interacts with someone more knowledgeable.

After Truscott's (1996) claim that, the grammatical error correction was ineffective in improving the writing process, teachers and researchers attempted to prove the effectiveness of the WCF (Bitchener et al., 2005). The debate over the effectiveness of CF is still an ongoing matter among investigators. There is still a need to add to the literature to justify correction in L2 writing. Psychological and individual factors are also among many topics that still need more research. Woolfolk, Winne, and Perry (2003) believed that it was unavoidable that individuals may differ from learning new information or selecting a proper method to learn a language. Dewaele (2005) argues that there is a lack of studies on the effect of psychological variables on the language acquisition process. However, there is an increasing interest in investigating psychological variables in recent decades. Success in learning a second language and its related areas, such as factors affecting it and the processes involved in it are some of the topics investigated in researches to come up with results, which would provide guidelines for learners as well as teachers in SL situations (Keshavarz, 2005).

To reach to this end, several studies have been carried out on characteristics of successful students (Anderson \& Elloumi, 2004; Hashemifardnia et al., 2018). Learning style is a name used to refer to cognitive style in educational settings. There is a general agreement among language acquisition investigators and theorist that cognitive and affective factors influence language learning and acquisition (Brown, 2007). According to Kagan (1985), cognitive style influences on the learners based on a number of factors such as how they form concepts, solve problems, think, select hypotheses, and process information. Jamiesson (1992), studied impulsivity/reflectivity and field-dependent/field-independent to provide a method for classifying successful and unsuccessful language learners.

Studies reveal that many models of cognitive styles have been proposed (Ehrman \& Leaver, 2003; Namaziandost et al., 2019; Reid, 1995; Skehan, 1998). The most comprehensive taxonomy of cognitive styles comes from Ehrman and Leaver (2003). This model consists of a superordinate construct, synopticectenic and ten subscales. Taheri and Khanlarzadeh (2016) maintained that synoptic learning is holistic, relies on intuition and subconscious control, whereas ectenic learning is atomistic, and occurs under the conscious control of the learner. The other ten subscales are (1) field sensitivity-field insensitivity, (2) fieldindependence-field-dependence, (3) random-sequential, (4) global-particular, (5) inductive-deductive, (6) synthesis-analysis, (7) analogue-digital, (8) concrete-abstract, (9) leveling-sharpening, (10) impulsivityreflectivity (p. 63). The cognitive scales to the left of the model (i.e., the first component of each subscale) tend to be synoptic, while those to the right tend to be analytic and more comfortable with grammar rules (Ehrman \& Leaver, 2003; Leaver et al., 2005).

According to Ehrman and Leaver (2003), field-independent learners "tend to extract the important parts from its context, while field-dependent learners prefer to treat the information in a more holistically way" (Ehrman \& Leaver, 2003, p. 404). Field-sensitive learners see the entire field as composed of interrelated 
Kivi, P. J., Hernández, R. M., Flores, J. L. E., Garay, J. P. P. \& Fuster-Guillén, D. (2021). The correlation between cognitive styles and written corrective feedback preferences among Iranian and Turkish EFL learners. Cypriot Journal of Educational Science. 16(2), 669-685 https://doi.org/10.18844/cjes.v16i2.5643

segments, but field-insensitive learners prefer not to make use of context and learn a language in isolated rules (Jabbari \& Fazilatfar, 2012). Random learners develop their own approaches to learn a language. Globals tend to attend to the whole picture and see the big picture. Particulars attend to discrete items and details first; that is, they move from form to meaning and use bottom-up processing (Kim, 201). Inductive-deductive scale refers to how learners deal with language rules. Inductive learners tend to start with specific examples and move to rules that are more general. Deductive learners who prefer to form rules to particular instances (Khorshidi \& Rassaei, 2013) prefer an opposing approach. Synthetic-analytic scale refers to the directionality of processing information (i.e., putting the information together or taking it apart). Synthetic learners tend to assemble known facts and build something new. Analytic learners, in contrast, prefer rules because they can break them down into smaller components. According to Ehrman and Leaver (2003), synthesizing is an unconscious process, whereas analyzing is a conscious process.

\section{Review of the Related Literature}

Most of the previous research concerning the use of CF supported the value of WCF (Bitchener et al., 2005). WCF, which is also named grammar correction or error correction, refers to the "correction of grammatical errors to improve a student's ability to write accurately" (Truscott, 1996, p. 329). Research has indicated that learners value teacher feedback and learners pay more considerable attention to this CF type than other forms, (e.g., audio feedback and self-evaluation) (Badger \& Yu, 2006; Yokota \& ljuin, 2009; Ziafar \& Namaziandost, 2019).

It is argued that students tend to receive more feedback on language learning matters; however, they also prefer teacher's comments on their writing tasks (Nasri et al., 2019; Kellogg, 2008). It is also argued that L2 learners regard significantly on writing accuracy, and they are so willing to solve their grammatical problems by the instructor (Genç, 2014; Komura, 1999). Some studies indicated that learners expect their writing teachers to provide comprehensive WCF on their writing assignments. In studies of CF, researchers have concluded differently on CF issues. For example, some studies suggested that direct CF might be more effective than other CF types (e.g. Halimi, 2008; Sahmadan, 2019; Talatifard; 2016), and in some other studies, indirect CF might be more effective (Almasi \& Nemat Tabrizi, 2016; Sadat et al., 2015). Bitchener (2012) believed that individual and contextual factors were the mediating factors affecting the extent to which students engage with WCF. Hashemian and Fadaei (2012) maintained that one of the most salient factors showing differences between $L 2$ learners is their cognitive style. In the following section, the studies on the contribution of cognitive styles and CF efficacy were taken into account.

In the first section, the studies on the contribution of field-dependency as a cognitive style were reviewed. Shojaei and Kapfo (2015) examined the effect of cognitive style (field-dependency) on SL students' general writing skill. They resulted that cognitive style had a significant impact on general writing skill. Rahimi (2015) aimed at finding the impact of individual differences (field-dependency and writing motivation) in the retention of teachers' WCF. Finally, He concluded that learners' field dependency and their successful short-term and long- term retention of WCF had a strong correlation. In another study, Darabad (2013) explored the correlation of two types of oral CF (prompts and recasts) on the oral accuracy of Iranian EFL students regarding their cognitive styles in terms of field-dependency. He found that there was no correlation between students' cognitive styles and types of feedback in terms of target language accuracy. Yoshida (2008) investigated teachers' choice and students' CF types preferences. The findings of this study indicated that teachers selected different CF types according to learners' cognitive styles and language abilities.

In this section, the studies on the contribution of reflectivity/impulsivity were reviewed. Keshavarz (2005) investigated the correlation between impulsivity/reflectivity as a continuum of cognitive style and language proficiency. He found a positive relationship between being reflective and good score in the 
Kivi, P. J., Hernández, R. M., Flores, J. L. E., Garay, J. P. P. \& Fuster-Guillén, D. (2021). The correlation between cognitive styles and written corrective feedback preferences among Iranian and Turkish EFL learners. Cypriot Journal of Educational Science. 16(2), 669-685 https://doi.org/10.18844/cjes.v16i2.5643

test. Nemat Tabrizi (2015) examined the impact of awareness-raising training on students' reading comprehension performance with a focus on reflective/impulsive cognitive style. It was found that the reflective learners have higher mean on reading test than impulsive ones. In addition, Moslemi and Dastgoshadeh (2017) aimed at examining the correlation between Iranian young adult learners' cognitive style written CF preferences. They found a strong correlation between students' cognitive style and their written CF preferences. However, some other studies found no relationship between cognitive style and second/foreign language (SL/FL) success. In another study, Salih Tasdemir and Yalcin Arsalan (2018) aimed to see the correlation between EFL learners' feedback preferences and their learning styles. Their findings indicated that there was no correlation between learners' learning styles and their CF preferences. Furthermore, Bazargani and Larsari (2013) have investigated the relationship between reflective/impulsive cognitive style and multiple-choice item performance and found the relationship as not significant.

As the literature shows, there are controversial findings regarding the correlation between SL/FL success and cognitive style and more studies were required. Moreover, another reason for this study was the lack of studies related to the relationship between cognitive styles and preferences of CF among learners, and the findings of this study could motivate other researchers in future studies in this field. The last reason for doing this research was to conduct this study in two educational contexts (i.e. Iran and Turkey). Accordingly, the purpose of this study was to examine the correlation between learner's cognitive styles and their WCF preferences. In other words, this study aimed to assist learners to enhance their L2 writing accuracy through a much clearer understanding of their cognitive styles.

Reviewing the literature so far, no studies have been done in Iranian context on Cognitive Styles and Written Corrective Feedback Preferences among Iranian and Turkish EFL Learners. Moreover, based on the different sides of the cognitive styles and its role in language learning, this study attempted to examine the correlation between cognitive styles and WCF preferences among Iranian EFL learners. Based on the purpose as mentioned above, the present study sought to answer the research questions below:

1. Is there any correlation between Iranian EFL students' cognitive styles and their WCF preferences in different types?

2. Is there any correlation between Turkish EFL students' cognitive styles and their WCF preferences in different types?

3. Is there any correlation between Iranian learners' cognitive styles and their preferences for different frequencies of error correction?

4. Is there any correlation between Turkish learners' cognitive styles and their preferences for different frequencies of error correction?

\section{Methodology}

\subsection{Participants}

The whole population of the present study were Iranian intermediate EFL learners. Sixty out of seventyfive EFL learners were chosen through a standardized placement test in this study. The placement test was an Oxford Placement Test (OPT) (2001). This test was done in two countries: Iran and Turkey. After administrating the proficiency test, a group of participants was selected based on one score above and below the mean. Thirty learners were considered as the Turkish participants and thirty learners were seen as the Iranian participants. Their age range was from 15 to 19.

\subsection{Instrumentations}


Kivi, P. J., Hernández, R. M., Flores, J. L. E., Garay, J. P. P. \& Fuster-Guillén, D. (2021). The correlation between cognitive styles and written corrective feedback preferences among Iranian and Turkish EFL learners. Cypriot Journal of Educational Science. 16(2), 669-685 https://doi.org/10.18844/cjes.v16i2.5643

3.2.1 Oxford Placement Test (2001): A standardized test was selected to homogenize learners' proficiency level. In the current research, the intermediate EFL learners were chosen through this standardized test. The OPT included 60 items in three general sections: grammar, vocabulary and reading. The items of the test were in multiple-choice format.

3.2.2 The Questionnaire of E \& L learning style: To identify subjects' cognitive styles, Ehrman and Leaver (2003) developed E and L Learning Style Questionnaire, and the translation of this questionnaire was used. This questionnaire involved thirty statements in a nine-point Likert type scale to determine learners' preferences on cognitive styles. Ehrman and Leaver (2003) specified three items for each of the ten style dimensions. These ten style dimensions are depended on the individual's preferences, state the students' general stylistic orientation information, represented by a superordinate scale of synopticectenic. Maftoon and Rezaie (2011) calculated the reliability of the whole, and each of the subscales of the questionnaire in the Persian version. The reliability of the whole questionnaire was 0.778 ; although the subscales reliability ranged between 0.571 , and 0.853 .

3.2.3 Corrective feedback questionnaire. Amrhein and Nassaji (2010) constructed a questionnaire to compare students' WCF preferences. The questionnaire items were designed based on previous studies (Amrhein \& Nassaji, 2010), which enhanced the questionnaire validity. This instrument involved three sections. The teacher applied section A to elicit information about students' preferences for various frequencies of error correction provided. Section B was designed to elicit information about learners' preferences for different WCF types. Seven question items are represented by this part, which requires the respondent to mark their preferences on a five-Likert scale. Six question items of the questionnaire refer to types of error, which were ranged in a five-Likert scale, and are represented by part C. Section C was designed to elicit information about students' preferences for different types of their errors to be corrected.

\subsection{Procedure}

Firstly, the teacher explained the purpose of this study to whole learners. In the next phase, the OPT was used to homogenize and select language learners based on the intermediate level in two contexts (Iran and Turkey). Thirty learners were considered as the Turkish participants and thirty learners were seen as the Iranian participants. After selecting the participants, the teacher distributed two questionnaires to the participants and they completed at the time of distribution to collect the data. The researcher gave detailed instructions on how to complete the questionnaires. Firstly, the $E$ \& L Learning Style Questionnaire was administered to divide the participants into two groups of synoptic and ectenic. The participants were needed to finish 30 items within a particular time limit during the $E$ \& L Learning Style Questionnaire. The participants selected the questionnaire items based on a nine-point Likert scale. Afterwards, to compare synoptic and ectenic students' WCF preferences, the learners' questionnaire was administered and both groups of participants were asked to select the best description in terms of efficiencies for various frequencies and each type of feedback and error to be corrected.

\subsection{Data Analysis}

The participants were divided into two groups as synoptic or ectenic depended on their responses on the E\&L Learning Styles Questionnaire in each context (Iran and Turkey), and then compared in terms of their WCF preferences. The questionnaire responses were recorded and analyzed through SPSS 22.0 for statistical analysis. In the first research question, in order to calculate the correlation between Iranian EFL students' cognitive styles and their WCF preferences in different types, the Pearson product-moment was used. In the research second research question, to calculate the correlation between Turkish EFL students' cognitive styles and their WCF preferences in different types, the Pearson product-moment was used. To analyze the data for the third and fourth research questions, as the data collected from the two 
Kivi, P. J., Hernández, R. M., Flores, J. L. E., Garay, J. P. P. \& Fuster-Guillén, D. (2021). The correlation between cognitive styles and written corrective feedback preferences among Iranian and Turkish EFL learners. Cypriot Journal of Educational Science. 16(2), 669-685 https://doi.org/10.18844/cjes.v16i2.5643

variables were nominal, the researcher applied the Chi-square formula to figure out the correlation between the two variables.

\section{Results}

\subsection{Results of the First Research Question}

In the first research question, the aim was to see the possible correlation between Iranian EFL students' cognitive styles and their different types of WCF preferences. Table 4.1 revealed descriptive statistics such as the percentage, and the frequency of the Iranian EFL learners concerning their cognitive styles.

Table 1. Cognitive Styles Frequency and Percentage of Iranian EFL Learners

\begin{tabular}{lccccc}
\hline & \multicolumn{2}{c}{ Frequency } & Percentage & Valid Percentage & Cumulative Percentage \\
\hline \multirow{3}{*}{ Valid } & Synoptic & 18 & & 60 & 60 \\
& Ectenic & 12 & 40 & 40 & 60 \\
& Total & 30 & 100 & 100 & 100 \\
& & &
\end{tabular}

The findings gained from Table 1 indicated that $60 \%$ of the Iranian EFL students had a synoptic cognitive style, and $40 \%$ of them had an ectenic cognitive style. The whole number of Iranian participants were 30. To answer the first research question, the Point bi-serial Correlation Coefficient Formula was applied to see the correlation between cognitive style and CF types in Table 2.

Table 2. Pearson Correlation of Cognitive Styles and Types of Corrective Feedback among Iranian Learners

\begin{tabular}{lccc}
\hline & & Cognitive Styles & Types of CF \\
\hline Cognitive Style & Pearson Correlation & 1 & $0.69^{* *}$ \\
& Sig. (2-tailed) & & 0.00 \\
N & 30 & 30 \\
Types of CF & Pearson Correlation & $0.69 * *$ & \\
& Sig. (2-tailed) & 0.00 & 30 \\
\hline
\end{tabular}

In Table 2, the results of the correlation between students' cognitive style and their different types of WCF preferences was statistically significant $[r=.69, N=30, p<.05]$. Table 3 indicated the frequency and percentage of feedback type chosen by synoptic cognitive style among Iranian students.

Table 3. Frequency and Percentage of Synoptic Style for Feedback Type of Iranian EFL Learners

\begin{tabular}{llcccc}
\hline \multirow{2}{*}{$\begin{array}{l}\text { Percentage } \\
\text { Clues or direction }\end{array}$} & Frequency & Percentage & Valid Percentage & Cumulative \\
\hline & Error identification & 92 & 27.29 & 27.29 & 27.29 \\
& Correction with comments & 41 & 12.16 & 12.16 & 39.45 \\
Valid & Overt Correction & 30 & 8.90 & 8.90 & 48.35 \\
& Commentary & 102 & 30.26 & 30.26 & 78.61 \\
\end{tabular}


Kivi, P. J., Hernández, R. M., Flores, J. L. E., Garay, J. P. P. \& Fuster-Guillén, D. (2021). The correlation between cognitive styles and written corrective feedback preferences among Iranian and Turkish EFL learners. Cypriot Journal of Educational Science. 16(2), 669-685 https://doi.org/10.18844/cjes.v16i2.5643

$\begin{array}{lcccc}\text { (comment with } & & & & \\ \text { no correction) } & & & & \\ \quad \text { No feedback } & 28 & 8.30 & 8.30 & 91.73 \\ \begin{array}{l}\text { Personal Comments on } \\ \text { Content }\end{array} & 21 & 6.23 & 6.23 & 100 \\ \text { Total } & 337 & 100 & 100 & \end{array}$

In Table 3, the frequency and percentage of feedback type chosen by synoptic cognitive style students were revealed. The findings of Table 3 showed that the percentage from the most to the least were: (1) Overt correction (30.26\%), (2) Clue or direction (27.29\%), (3) Error identification (12.16\%), (4) Correction with comments (8.90\%), (5) No feedback (8.30\%), (6) Commentary (6.82\%), and (7) Personal comments (6.23\%). Table 4 indicates the frequency and percentage of feedback type selected by ectenic students.

Table 4. Frequency and Percentage of Ectenic Style for Feedback Type of Iranian Learners

\begin{tabular}{lcccc}
\hline \multirow{2}{*}{ Percentage } & Frequency & Percentage & Valid Percentage & Cumulative \\
\hline \multirow{2}{*}{ Clues or direction } & 69 & 18.80 & 18.80 & 18.80 \\
Error identification & 58 & 15.80 & 15.80 & 34.6 \\
$\quad$ Correction with comments & 47 & 12.80 & 12.80 & 47.4 \\
$\quad$ Overt Correction & 118 & 32.15 & 32.15 & 79.55 \\
Commentary & 18 & 4.90 & 4.90 & 84.45 \\
$\quad$ comment with & & & & \\
$\quad$ no correction) & 12 & 3.26 & 3.26 & 87.71 \\
$\quad$ No feedback & 45 & 12.26 & 12.26 & 100 \\
$\quad$ Personal Comments on & & & & \\
Content & 367 & 100 & 100 & \\
Total & & & & \\
\hline
\end{tabular}

In Table 4, the frequency and percentage of feedback type chosen by ectenic students were indicated. The findings of this Table showed that the percentage from the most to the least were: (1) Overt correction (32.15\%), (2) Clue or direction (18.80\%), (3) Error identification (15.80\%), (4) Correction with comments (12.80\%), (5) Personal comments on content (12.26\%), (6) Commentary (4.90\%), and (7) No feedback (3.26\%).

\subsection{Results of the Second Research Question}

In the second question, the purpose was to see the possible relationship between Turkish students' cognitive styles and their different types of WCF preferences. Table 5 reveals descriptive statistics such as the percentage and the frequency of the Turkish EFL learners concerning their cognitive styles. 
Kivi, P. J., Hernández, R. M., Flores, J. L. E., Garay, J. P. P. \& Fuster-Guillén, D. (2021). The correlation between cognitive styles and written corrective feedback preferences among Iranian and Turkish EFL learners. Cypriot Journal of Educational Science. 16(2), 669-685 https://doi.org/10.18844/cjes.v16i2.5643

Table 5. Frequency and Percentage of Cognitive Styles of Turkish Learners

\begin{tabular}{lcccccc}
\hline & \multicolumn{2}{c}{ Frequency } & Percentage & \multicolumn{2}{c}{ Valid Percentage } & Cumulative Percentage \\
\hline \multirow{3}{*}{ Valid } & Synoptic & 15 & & 50 & 50 & 50 \\
\cline { 2 - 7 } & Ectenic & 15 & 50 & 50 & 100 \\
\cline { 2 - 6 } & Total & 30 & 100 & 100 & \\
\hline
\end{tabular}

The findings gained from Table 5 indicated that $50 \%$ of the Turkish students had a synoptic cognitive style and $50 \%$ of them had an ectenic cognitive style. The whole number of Turkish participants were 30. To answer the second question, the Point bi-serial Correlation Coefficient Formula was run to see the correlation between cognitive style and CF types among Turkish learners in Table 6.

Table 6. Pearson Correlation of Cognitive Styles and CF Types among Turkish Learners

\begin{tabular}{|c|c|c|c|}
\hline & & Cognitive Styles & Types of CF \\
\hline \multirow[t]{3}{*}{ Cognitive Style } & Pearson Correlation & 1 & $0.61 * *$ \\
\hline & Sig. (2-tailed) & & 0.01 \\
\hline & $N$ & 30 & 30 \\
\hline \multirow[t]{3}{*}{ Types of CF } & Pearson Correlation & $0.61 * *$ & \\
\hline & Sig. (2-tailed) & 0.01 & \\
\hline & $\mathrm{N}$ & 30 & 30 \\
\hline
\end{tabular}

Table 6 indicated the results of the correlation between students' cognitive style and scores gained from their preferences for different WCF types was statistically significant $[r=.61, N=30, p<.05]$. Table 7 indicates the frequency and percentage of feedback type chosen by ectenic students.

Table 7. Frequency and Percentage of Synoptic Style for Feedback Type of Turkish Learners

\begin{tabular}{|c|c|c|c|c|c|c|}
\hline \multirow{2}{*}{\multicolumn{2}{|c|}{ Percentage }} & \multirow{3}{*}{$\begin{array}{c}\text { Frequency } \\
71\end{array}$} & \multicolumn{2}{|c|}{ Percentage } & Valid Percentage & \multirow[t]{2}{*}{ Cumulative } \\
\hline & & & & & & \\
\hline \multirow{8}{*}{ Valid } & Clues or direction & & 20.17 & 20.17 & 20.17 & \\
\hline & Error identification & 62 & 17.61 & 17.61 & 37.78 & \\
\hline & Correction with comments & 70 & 19.88 & 19.88 & 57.66 & \\
\hline & Overt Correction & 91 & 25.85 & 25.85 & 83.51 & \\
\hline & $\begin{array}{l}\text { Commentary } \\
\text { (comment with } \\
\text { no correction) }\end{array}$ & 10 & 2.84 & 2.84 & 86.35 & \\
\hline & No feedback & 19 & 5.39 & 5.39 & 91.74 & \\
\hline & $\begin{array}{l}\text { Personal Comments on } \\
\text { Content }\end{array}$ & 29 & 8.23 & 8.23 & 100 & \\
\hline & Total & 352 & 100 & 100 & & \\
\hline
\end{tabular}

In Table 7, the frequency and percentage of feedback type chosen by synoptic students in Turkey were revealed. The findings of this Table showed that the percentage from the most to the least were: (1) Overt correction (25.85\%), (2) Clue or direction (20.17\%), (3) Correction with comments (19.88\%), (4) Error identification (17.61\%), (5) Personal comments on content (8.23\%), (6) No feedback (5.39\%), and (7) Commentary (2.84\%). Table 8 indicates the frequency and percentage of feedback types chosen by ectenic students in Turkey. 
Kivi, P. J., Hernández, R. M., Flores, J. L. E., Garay, J. P. P. \& Fuster-Guillén, D. (2021). The correlation between cognitive styles and written corrective feedback preferences among Iranian and Turkish EFL learners. Cypriot Journal of Educational Science. 16(2), 669-685 https://doi.org/10.18844/cjes.v16i2.5643

Table 8. Frequency and Percentage of Ectenic Style for Feedback Type of Turkish Learners

\begin{tabular}{|c|c|c|c|c|c|c|}
\hline \multicolumn{2}{|c|}{ Percentage } & \multirow{2}{*}{$\begin{array}{c}\text { Frequency } \\
59\end{array}$} & Percentage & \multicolumn{2}{|c|}{ Valid Percentage } & \multirow[t]{2}{*}{ Cumulative } \\
\hline \multirow{8}{*}{ Valid } & Clues or direction & & 16.52 & 16.52 & 16.52 & \\
\hline & Error identification & 63 & 17.64 & 17.64 & 34.16 & \\
\hline & Correction with comments & 75 & 21.00 & 21.00 & 55.16 & \\
\hline & Overt Correction & 100 & 28.01 & 28.01 & 83.17 & \\
\hline & $\begin{array}{l}\text { Commentary } \\
\text { (comment with } \\
\text { no correction) }\end{array}$ & 26 & 7.28 & 7.28 & 90.45 & \\
\hline & No feedback & 16 & 4.48 & 4.48 & 94.93 & \\
\hline & $\begin{array}{l}\text { Personal Comments on } \\
\text { Content }\end{array}$ & 18 & 5.04 & 5.04 & 100 & \\
\hline & Total & 357 & 100 & 100 & & \\
\hline
\end{tabular}

In Table 8, the frequency and percentage of feedback Type chosen by ectenic students in Turkey were indicated. The findings of this Table showed that the percentage from the most to the least were: (1) Overt correction (28.01\%), (2) Correction with comments (21.00\%), (3) Error identification (17.64\%), (4) Clue or direction (16.52\%), (5) Commentary (7.28\%), (6) Personal comments on content (5.04\%), and (7) No feedback (4.48\%).

\subsection{Results of the Third Research Question}

To analyze the third question relating the correlation between students' cognitive styles and their different frequencies of error correction preferences, the Chi-square Formula was done. Table 4.9 shows the cases number for cognitive style and the frequency of CF among Iranian learners.

Table 9. Cases Number for Cognitive Style and the Frequency of CF among Iranian Learners

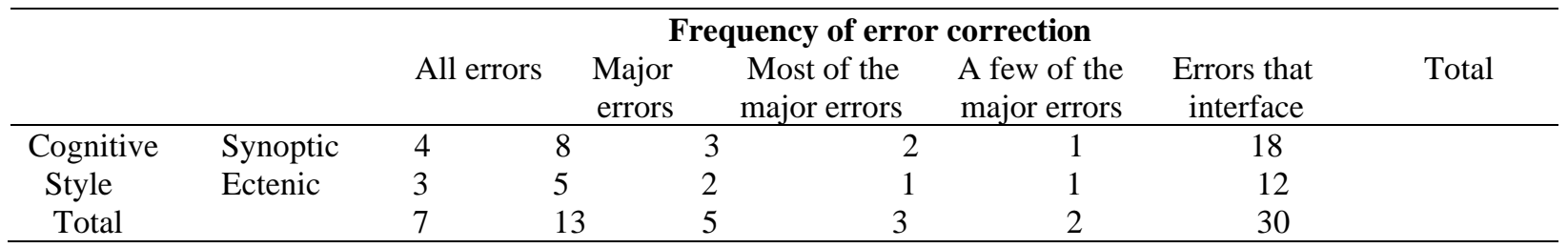

The result of Table 9 showed that, out of 18 Iranian students who had the synoptic style, most of them $(\mathrm{N}=8)$ believed that teachers should mark most of the major errors, and four of them believed that teachers should mark all errors. In similar vein, as for the ectenic style, out of 12 Iranian learners, most of them $(N=5)$ believed that teachers should mark the major errors, and three of them believed that teachers should mark all errors. Table 10 reveals the correlation between students' cognitive styles and their different frequencies of CF preferences.

Table 10. Chi-Square Tests for Frequency of CF among Iranian Learners

\begin{tabular}{|c|c|c|c|}
\hline & Value & $d f$ & Asymp. Sig. (2sided) \\
\hline Pearson Chi-Square & $6.381 a$ & 4 & .394 \\
\hline Likelihood Ratio & 6.010 & 4 & .256 \\
\hline Linear-by-Linear Association & .512 & 1 & .493 \\
\hline $\mathrm{N}$ of Valid Cases & & & \\
\hline
\end{tabular}


Kivi, P. J., Hernández, R. M., Flores, J. L. E., Garay, J. P. P. \& Fuster-Guillén, D. (2021). The correlation between cognitive styles and written corrective feedback preferences among Iranian and Turkish EFL learners. Cypriot Journal of Educational Science. 16(2), 669-685 https://doi.org/10.18844/cjes.v16i2.5643

a Eight cells (80.0\%) have expected count less than 5. The minimum expected count is .91 .

Table 10 revealed that the correlation between Iranian students' cognitive styles and their preferences for different frequencies of CF was not significant and the hypothesis was accepted.

\subsection{Results of the Fourth Research Question}

To analyze the fourth question relating the possible correlation between students' cognitive styles and their preferences for different CF frequencies, the Chi square Formula was utilized. Table 11 shows the cases number for cognitive style and the CF frequency among Turkish learners.

Table 11. Cases Number for Cognitive Style and the CF Frequency among Turkish Learners

\begin{tabular}{|c|c|c|c|c|c|c|c|c|}
\hline & \multicolumn{8}{|c|}{ Frequency of error correction } \\
\hline & & & & $\begin{array}{l}\text { Major } \\
\text { errors }\end{array}$ & $\begin{array}{l}\text { Most of the } \\
\text { major errors }\end{array}$ & $\begin{array}{l}\text { A few of the } \\
\text { major errors }\end{array}$ & $\begin{array}{c}\text { Errors that } \\
\text { interface }\end{array}$ & Total \\
\hline Cognitive & Synoptic & 6 & 4 & 2 & 2 & 1 & 15 & \\
\hline Style & Ectenic & 5 & 5 & 3 & 1 & 1 & 15 & \\
\hline Total & & 11 & 9 & 5 & 3 & 2 & 30 & \\
\hline
\end{tabular}

The result of Table 11 showed that, out of 15 Turkish students who had the synoptic style, most of them $(\mathrm{N}=6)$ believed that teachers should mark all errors, and four of them believed that teachers should mark most of the major errors. As for the ectenic style, out of 15 Turkish learners, most of them $(N=5)$ believed that teachers should mark both all errors and major errors, and three of them believed that teachers should mark most of the major errors. Table 12 reveals the correlation between students' cognitive styles and their preferences for different CF frequencies among Turkish learners.

Table 12. Chi-Square Tests for Frequency of CF among Turkish Learners

\begin{tabular}{|c|c|c|c|}
\hline & Value & $d f$ & Asymp. Sig. (2sided \\
\hline Pearson Chi-Square & $5.873^{a}$ & 4 & .341 \\
\hline Likelihood Ratio & 5.963 & 4 & .293 \\
\hline $\begin{array}{l}\text { Linear-by-Linear Association } \\
\mathrm{N} \text { of Valid Cases }\end{array}$ & .513 & 1 & .414 \\
\hline
\end{tabular}

a Seven cells (70.0\%) have expected count less than 5 . The minimum expected count is .83 .

Table 12 revealed that the correlation between Turkish students' cognitive styles and their preferences for different CF frequencies was not significant and the hypothesis was accepted.

\section{Discussion}

Feedback is seen as a necessity to enhance L2 teaching and learning (Leki, 2007). There are various types of CF practices, and it depends on the learner's learning style. In other words, different studies reveal that $\mathrm{L} 2$ learners have different cognitive learning styles and prefer different $\mathrm{CF}$ types. This research aimed at investigating the correlation between learner's cognitive styles and their WCF preferences. For this aim, two questionnaires, including CF questionnaire of Amrhein and Nassaji (2010) and learning styles questionnaire (Ehrman \& Leaver (2003) were adopted. The Persian versions of the instruments were distributed among the participants. The gathered data were analyzed and the findings were tabulated. In this section, the findings are discussed, and answers are provided for the questions of the study.

This study involved four questions: The first question attempted to find the possible correlation 
Kivi, P. J., Hernández, R. M., Flores, J. L. E., Garay, J. P. P. \& Fuster-Guillén, D. (2021). The correlation between cognitive styles and written corrective feedback preferences among Iranian and Turkish EFL learners. Cypriot Journal of Educational Science. 16(2), 669-685 https://doi.org/10.18844/cjes.v16i2.5643

between Iranian students' (synoptic-ectenic) cognitive styles and their different WCF types preferences. The result of the first question indicated that there was a correlation between learners' cognitive styles and their preferences for different errors types to be corrected. The findings of this research question were in line with the previous studies (e.g. Brown, 2007; Ellis, 2012; Irwin, 2017; Moslemi \& Dastgoshadeh, 2017). Ellis (2012) confirmed that learning styles have a noticeable effect in the language learning process in general and they have a relationship with CF in particular.

The first question finding also showed that the most selected feedback types for both synoptic and ectenic students were overt correction and clue or direction. Although the mean responses of the perception of synoptic students revealed that, this group disagree with personal comment with contents. The mean responses of the perception of synoptic students revealed that this group disagree with no correction. The results were consistent with the previous studies (Ehrman \& Leaver, 2003; Moslemi \& Dastgoshadeh, 2017).

The second question investigated the possible correlation between Turkish learners' (synoptic-ectenic) cognitive styles and their preferences for different WCF types. The second question results indicated that there was a relationship between learners' cognitive styles and their preferences for different types of errors to be corrected. As similar as the first research question's findings, the findings of this research question were in line with the previous studies (Ellis, 2012; Moslemi \& Dastgoshadeh, 2017; Robinson, 2002; Salih Tasdemir \& Yalcin Arsalan, 2018). Robinson (2002) stated that individual factors (specifically affective and cognitive factors) as crucial factors mediate between instruction and L2 learning. The results were also in line with Yoshida's study (2008), which maintained that teachers selected different CF types based on learners' language ability and cognitive styles. The findings also were consistent with Rahimi's (2015) study, which demonstrated a positive effect on cognitive factors on teachers' CF retention. Unlike the consistent results of other studies, Bazargani and Larsari (2013) found that there was no significant relationship between cognitive styles and $\mathrm{CF}$, and this finding was not consistent with the present research.

The finding of the second research question also showed that the findings showed that the most selected feedback type for both synoptic and ectenic Turkish students was overt correction. Although the mean responses of the perception of synoptic students indicated that, this group disagree with commentary. The mean responses of the perception of synoptic learners showed that this group disagree with no feedback. Based on the result of this question and regarding Ellis's (2009) CF typology, the findings indicated that synoptic students selected indirect correction (Almasi \& Nemat Tabrizi, 2016; Sadat et al., 2015), while ectenics preferred to be corrected directly (Halimi, 2008; Sahmadan, 2019).

The third question investigated the possible correlation between Iranian students' cognitive styles and their preferences for different CF frequencies. The results showed that the correlation between Iranian students' cognitive styles and their preferences for different CF frequencies was not significant. The result of this question was congruent with Bazargani and Larsari's (2013) study. According to Ehrman and Leaver (2003), "synoptic learners are often both field-independent and field-sensitive, so they are more autonomous, it was expected that they preferred less correction to be provided on their written works" (p 65).

The last research question investigated the possible correlation between Turkish students' cognitive styles and their preferences for different CF frequencies. The results showed that the correlation between Turkish students' cognitive styles and their preferences for different CF frequencies was not significant. The results of this question were consistent with the previous studies (Abedi et al., 2019; Atma \& Widiati, 2016). 
Kivi, P. J., Hernández, R. M., Flores, J. L. E., Garay, J. P. P. \& Fuster-Guillén, D. (2021). The correlation between cognitive styles and written corrective feedback preferences among Iranian and Turkish EFL learners. Cypriot Journal of Educational Science. 16(2), 669-685 https://doi.org/10.18844/cjes.v16i2.5643

\section{Conclusion and Pedagogical Implications}

The current research studied the correlation between Iranian and Turkish learner's cognitive styles and their WCF preferences. As the findings of this research emphasized a correlation between both Iranian and Turkish learners' cognitive styles and their preferences for different WCF types, teachers and investigators require identifying their learners' individual styles and matching their instruction methods with learners' learning styles.

The finding of the research showed that the most selected feedback types for both synoptic and ectenic learners in the Iranian context were overt correction and clue or direction. Although the mean responses of the perception of synoptic students showed that, this group disagree with personal comment with contents. The mean responses of the perception of synoptic students showed that this group disagree with no correction. Moreover, the finding of the research question also revealed that the most selected CF types for both synoptic and ectenic Turkish students was overt correction. However, the mean responses of the perception of synoptic learners demonstrated that this group disagree with commentary.

Based on the results of this research, several implications were taken into account. To determine the appropriate instructional methods and select the most proper CF approach by instructors, they require noticing the important role played by their students' needs and individual differences in the process of language learning (Ferris, Liu, Sinha, \& Senna as cited in Rahimi, 2015). In this regard, teachers and researchers have to pay more considerable attention to their differences.

Since the study findings proved a correlation between learners' cognitive styles and their preferences for different WCF types, teachers require identifying their students' individual styles and match their instruction methods with learners' learning styles.

On the basis of the results and conclusion of this study and also on the basis of experience gained during the completion of the various stages of this investigation, two suggestions for further studies have been made and these are as follows:

The first suggestion is that a large number of participants could be used from different English language institutes and universities and studies should be carried out. Besides, it is suggested the following studies can be carried out in different educational contexts in different countries.

\section{References}

Abedi, P., Namaziandost, E., \& Akbari, S. (2019). The impact of flipped classroom instruction on Iranian upperintermediate EFL learners' writing skill. English Literature and Language Review, 5(9), 164-172. https://ideas.repec.org/a/arp/ellrar/2019p164-172.html.

Al-Hebaishi, S. M. (2012). Investigating the relationships between learning styles, strategies on Iranian EFL learners' writing accuracy. Journal of Applied Linguistics and Language Research, 3(1), 74-85. http://journals.aiac.org.au/index.php/IJALEL/article/view/4283.

Aliakbari, M., \& Qasemi, N. (2012). On the relationship between Iranian EFL learners' learning style preference and their gender, proficiency level and achievement score. International Journal of Pedagogies and Learning, 7(3), 275-283. doi:10.5172/ijpl.2012.7.3.275.

Almasi, E. \& Nemat Tabrizi, A. R. (2016). The effects of direct vs. indirect corrective feedback and the academic performance of Saudi English majors. International Interdisciplinary Journal of Education, 1(8), 510-519. http://www.jallr.com/index.php/JALLR/article/view/237.

Amrhein, H. R., \& Nassaji, H. (2010). Written corrective feedback: What do students and teachers prefer and why? Canadian Journal of Applied Linguistics, 13, 95-127. https://eric.ed.gov/?id=EJ944129. 
Kivi, P. J., Hernández, R. M., Flores, J. L. E., Garay, J. P. P. \& Fuster-Guillén, D. (2021). The correlation between cognitive styles and written corrective feedback preferences among Iranian and Turkish EFL learners. Cypriot Journal of Educational Science. 16(2), 669-685 https://doi.org/10.18844/cjes.v16i2.5643

Anderson, T. \& Elloumi, F. (2004). Theory and Practice of On-line Learning. Athabasca University. Canada.

Atma, N., \& Widiati, U. (2016). EFL students' preferences for corrective feedback in speaking instruction across peaking course levels. Bahasa dan Seni, 43(2), 183-195. https://core.ac.uk/download/pdf/230958689.pdf.

Badger, D. \& Yu, F. (2006). Student reactions to teacher commentary on student revision TESOL Quarterly, 31, 315339.

http://www.fed.cuhk.edu.hk/ aflwrite/article/Student\%20reactions\%20to\%20teacher\%20feedback.pdf.

Bazargani, D.T., \& Larsari, V. N. (2013). Impulsivity-reflectivity, gender and performance on multiple choice items. International Journal of Language Learning and Applied Linguistics World (IJLLALW), 4(2), 213-230. http://jal.iaut.ac.ir/article_541065_fdb9fff9231e556dae0ed75def5da6fe.pdf.

Behroozi, B., \& Karimnia, A. (2017). Educational context and ELT teachers' corrective feedback preference: Publicand private school teachers in focus. International Journal of Research in English Education, 2(2), 10-15. http://ijreeonline.com/article-1-42-en.html.

Bitchener, J. \& Knoch, U. (2010). The contribution of written corrective feedback to language development: A tenmonth investigation. Applied Linguistics, 31. 193-214. 10.1093/applin/amp016.

Bitchener, J. (2012). Written Corrective Feedback in Second Language Acquisition and Writing. New York, NY: Routledge.

Bitchener, J., (2008). Evidence in support of written corrective feedback. Journal of Second Language Writing, 17(2), 102-118. 10.1016/j.jslw.2007.11.004.

Bitchener. J., Young, S., \& Cameron, J. (2005). The effect of different types of corrective feedback on ESL student writing. Journal of Second Language Writing, 191-319. https://citeseerx.ist.psu.edu/viewdoc/download?doi=10.1.1.578.6084\&rep=rep1\&type=pdf.

Brown, H. D. (2007). Teaching by principles: An interactive approach to language pedagogy (3 ${ }^{\text {rd }}$ ed.). White Plains, US: Pearson Education.

Carless, D. (2006). Differing perceptions in the feedback process. Studies in Higher Education, 31(2), $219-233$. https://www.tandfonline.com/doi/abs/10.1080/03075070600572132.

Chiya, S. (2003). The importance of learning styles and learning strategies in EFL teaching in Japan. Japan: Susaki Technical High School, Kochi Prefecture. https://citeseerx.ist.psu.edu/viewdoc/download?doi=10.1.1.483.6182\&rep=rep1\&type=pdf.

Darabad, A. M. (2013). Does language aptitude make a difference? An investigation of the effect on oral accuracy through corrective feedback. International Journal of Linguistics, 5(4), 225-244. http://doi.org/10.5296/ijl.v5i4.4199.

DeKeyser, R. M. (2007). Introduction: Situating the concept of practice. In R. M. DeKeyser (Ed.), Practice in a second language: Perspectives from applied linguistics and cognitive psychology (pp. 1-18). Cambridge: Cambridge University Press.

Dewaele, J.-M. (2005). Investigating the psychological and emotional dimensions in instructed language learning: Obstacles and possibilities. Modern Language Journal, 89(3), 367-380. https://onlinelibrary.wiley.com/doi/abs/10.1111/j.1540-4781.2005.00311.x.

Ehrman, M., \& Leaver, B. L. (2003). Cognitive styles in the service of language learning. System, 31(3), $393-415$. http://doi.org/10.1016/S0346-251X(03)00050-2.

Ellis, R. (2009). A typology of written corrective feedback types. English Language Teaching Journal, 63(2), 97-107. http://doi.org/10.1093/elt/ccn023.

Ellis, R. (2012). Language teaching research and language pedagogy. Oxford, UK: Wiley Blackwell. http:// doi.org/10.1002/9781118271643. 
Kivi, P. J., Hernández, R. M., Flores, J. L. E., Garay, J. P. P. \& Fuster-Guillén, D. (2021). The correlation between cognitive styles and written corrective feedback preferences among Iranian and Turkish EFL learners. Cypriot Journal of Educational Science. 16(2), 669-685 https://doi.org/10.18844/cjes.v16i2.5643

Genç, Z. S. (2014). Correcting spoken errors in English language teaching: Preferences of Turkish EFL learners at different proficiency levels. Egitim ve Bilim, 39 ,259-271. 10.15390/EB.2014.1438.

Guenette, D. (2007). Is feedback pedagogically correct? Research design issues in studies of feedback on writing. Journal of Second Language Writing, 16(1), 40-53. 10.1016/j.jslw.2007.01.001.

Halimi, S. (2008). Indonesian teachers' and students' preferences for error correction. Wacana, 10(1), 50-71. https://media.neliti.com/media/publications/180747-EN-indonesian-teachers-and-students-prefere.pdf.

Hashemian. M., \& Fadaei, B. (2012). L2 Learners' strategy preference in metaphorical test performance: Effects of working memory and cognitive style. Issues in Language Teaching, 1(2), 279-231. https://ilt.atu.ac.ir/article_1345_39de8a2ffb49b10588005507bda52f13.pdf.

Hashemifardnia, A., Namaziandost, E., \& Sepehri, M. (2018). The effectiveness of giving grade, corrective feedback, and corrective feedback-plus-giving grade on grammatical accuracy. International Journal of Research Studies in Language Learning, 8 (1), 15-27. https://papers.ssrn.com/sol3/papers.cfm?abstract_id=3463040.

Hashemifardnia, A., Namaziandost, E., Shafiee, S. (2018). The effect of implementing flipped classrooms on Iranian junior high school students' reading comprehension. Theory and Practice in Language Studies, 8(6), 665673. https://www.academypublication.com/ojs/index.php/tpls/article/view/tpls0806665673.

Hashemifardnya, A., Namaziandost, E., \& Rahimi, M. (2017). The role of lexical chunks in learning ESP terms among Iranian computer engineering students. Language Education Studies, 3 (4), 10-23. http://www.languageeducationstudies.ir/upload/2-LES17342-Namazian-et-al-(2017).pdf.

Hattie, J. \& Timperley, H. (2007). The power of feedback. Review of Educational Research. 77, 81-112. $10.3102 / 003465430298487$.

Hsu, P. S., \& Dwyer, F. (2004). Effect of level of adjunct questions on achievement of field (in)dependent learners. International Journal of Instructional Media, 31(1), 99-106. https://journals.scu.ac.ir/article_13797.html.

Hyland, F. (2001). Providing effective support: investigating feedback to distance language learners. Open Learning, 16(3), 233-247. https://www.tandfonline.com/doi/abs/10.1080/02680510120084959.

Jabbari, A., \& Fazilatfar, A. M. (2012). The role of errortypes and feedback in Iranian EFL classrooms. International Journal of English Linguistics, 2(1), 135-148. doi:10.5539/ijel.v2n1p135.

Kagan, S. (1985). Dimensions of cooperative classroom structures. In R. Slavin, S. Sharan, S. Kagan, R. Hertz Lazarowitz, C. Webb, \& R. Schmuck (Eds.), Learning to cooperate, cooperating to learn (pp. 67-96). New York: Plenum Press.

Kellogg, R. T. (2008). Training writing skills: A cognitive developmental perspective. Journal of Writing Research, 1, 1-26. https://neillthew.typepad.com/files/training-writing-skills.pdf.

Keshavarz, M. H., (2005). On the relationship between impulsivity/reflectivity cognitive style and language proficiency test performance. Retrieved form www.SID.ir.

Khorshidi, E., \& Rassaei, E. (2013). The effects of learners' gender on their preferences for corrective feedback. Journal of Studies in Learning and Teaching English,2(2),71-83. http://journals.iau.ir/article_518965_b98e910ab76dc1858f8e8f43b86de9f6.pdf.

Kim, K. (2015). Similarities and differences between teachers' and students' views on corrective feedback-Korean context. The Bridge: Journal of Educational Research-Informed Practice, 2(3), 42-70.

Leaver, B. L., Ehrman, M., \& Shekhtman, B. (2005). Achieving success in second language acquisition. Cambridge: Cambridge University Press.

Leki, I. (2007). A synthesis of research on second language writing in English. A Synthesis of Research on Second Language Writing in English. 1-259. 10.4324/9780203930250.

Long, M. H. (1997). Focus on form in Task-Based Language Teaching. Retrieved on April 27, 2019. from 
Kivi, P. J., Hernández, R. M., Flores, J. L. E., Garay, J. P. P. \& Fuster-Guillén, D. (2021). The correlation between cognitive styles and written corrective feedback preferences among Iranian and Turkish EFL learners. Cypriot Journal of Educational Science. 16(2), 669-685 https://doi.org/10.18844/cjes.v16i2.5643

http://www.mhhe.com/socscience/foreignlang/top.htm.

McLaughlin, M.W. (1990). Enabling professional development: What have we learned? In Lieberman, A. \& Miller, L. (eds) Staff development and school change: New demands, new realities, new Argmegtlygl. New York: Teachers College Press.

Moslemi, N., \& Dastgoshadeh, A. (2017). The relationship between cognitive styles and young adult learners' preferences for written corrective feedback. HOW, 24(2), 11-34. http://dx.doi.org/10.19183/how.24.2.338.

Namaziandost, E., Pourhosein Gilakjani, A., \& Hidayatullah (2020). Enhancing pre-intermediate EFL learners' reading comprehension through the use of Jigsaw technique. Cogent Arts \& Humanities, 7(1), 1-15. https://www.tandfonline.com/doi/full/10.1080/23311983.2020.1738833.

Namaziandost, E., Razmi, M.H., Heidari, S., Tilwani, S. A. (2020). A contrastive analysis of emotional terms in bednight stories across two languages: Does it affect learners' pragmatic knowledge of controlling emotions? Seeking implications to teach English to EFL learners. Journal of Psycholinguistic Research 49 (6), 1047-1065. https://doi.org/10.1007/s10936-020-09739-y.

Namaziandost, E., Shatalebi, V., \& Nasri, M. (2019). The impact of cooperative learning on developing speaking ability and motivation toward learning English. Journal of Language and Education, 5(3), 83-101. https://doi.org/10.17323/jle.2019.9809.

Nasri, M., Namaziandost, E., \& Akbari, S. (2019). Impact of pictorial cues on speaking fluency and accuracy among Iranian pre-intermediate EF learners. International Journal of English Language and Literature Studies, 8(3), 99-109. https://ideas.repec.org/a/asi/ijells/2019p99-109.html.

Nemat-Tabrizi, A. R. (2015). The relationship between critical thinking and cognitive and metacognitive learning strategies among Iranian EFL learners. International Journal of Language Learning and Applied Linguistics World, 7(1), 265-277. https://jte.sru.ac.ir/article_283_1d45ec094b17734db337c045ad602f6b.pdf.

Polio, Ch. (2003). "Research on Second Language Writing: An Overview of What We Investigate and How." Exploring the Dynamics of Second Language Writing. Ed., Barbara, Kroll. Cambridge: Cambridge UP. 35-65.

Radecki, P., \& Swales, J. (1988). ESL student reaction to written comments on their written work. System, 16, 355365. http://hdl.handle.net/2027.42/27547.

Rahimi, M. (2015). The role of individual differences in learners' retention of written corrective feedback. Journal of Response to Writing, 1(1), 19-48. https://journalrw.org/index.php/jrw/article/view/18.

Robinson, P. (2002). Individual differences and instructed language learning. Amsterdam, NL: John Benjamins. http://doi.org/10.1075/Illt.2.

Sadat, T., Zarifi, A., Sadat, A., \& Malekzadeh, J., (2015). Effectiveness of direct and indirect corrective feedback on Iranian EFL learner's accuracy and retention of conditional sentences types I, II \& III. Theory and Practice in $\begin{array}{lll}\text { Language Studies, 20-23. } & \text { 5(10), }\end{array}$ http://www.academypublication.com/ojs/index.php/tpls/article/view/tpls051020232028.

Sahmadan, S. (2019). The effect of direct written corrective feedback to improve second grade students' writing ability. Journal of English Teaching and Learning, 8(2), 23-30. http://riset.unisma.ac.id/index.php/LANG/article/view/2862

Sampson, A. (2012). Coded and uncoded error feedback: effects on error frequencies in adult Colombian EFL learners' writing. System, 40(4), 494-504. http://dx.doi.org/10.1016/j.system.2012.10.001.

Shakibaei, G., Shahamat, F., \& Namaziandost, E. (2019). The effect of using authentic texts on Iranian EFL learners' incidental vocabulary learning: The case of English newspaper. International Journal of Linguistics, Literature and Translation (IJLLT), 2(5), 422-432. https://alkindipublisher.com/index.php/ijllt/article/view/618.

Shojaei, F., \& Kapfo, K. (2015). A study of cognitive styles effect on ESL students' general writing ability. International 
Kivi, P. J., Hernández, R. M., Flores, J. L. E., Garay, J. P. P. \& Fuster-Guillén, D. (2021). The correlation between cognitive styles and written corrective feedback preferences among Iranian and Turkish EFL learners. Cypriot Journal of Educational Science. 16(2), 669-685 https://doi.org/10.18844/cjes.v16i2.5643

Journal of Research, 2(9), 94-99.

Swain, M. (1995). 'Three functions of output in second language learning' in G. Cook and B. Seidelhofer (Eds.): Principle and Practice in Applied Linguistics: Studies in honor of H.G. Widdowson. Oxford: Oxford University Press, pp. 125-44.

Taheri, P., \& Khanlarzadeh, M. (2016). On the relation-ship between EFL learners' socio-economic status and their attitudes toward oral corrective feedback: A mixed-method study. English Language Teaching, 2(4), 75-59. https://jmrels.journals.ikiu.ac.ir/article_807.html.

Talatifard, S. (2016). The Effect of reactive focused corrective feedback on Iranian EFL learners' writing performance. Journal of Advances in English Language Teaching, 4(3), pp.40-48. file:///C:/Users/Hp/AppData/Local/Temp/4675-11013-2-PB.pdf.

Tasdemir, M. S., \& Arslan, F. Y. (2018). Feedback preferences of EFL learners with respect to their learning styles. Cogent Education, 5(1), 1-18. DOI: 10.1080/2331186X.2018.1481560.

Truscott, J. (1996). The case against grammar correction in L2 writing classes. Language Learning, 46(2), 327-369. http://doi.org/10.1111/j.1467-1770.1996.tb01238.x.

Van Beuningen, C. (2010). Corrective feedback in L2 writing: Theoretical perspectives, empirical insights, and future $\begin{array}{llllll}\text { directions. International Journal of English Studies, } & \text { 10, }\end{array}$ http://revistas.um.es/ijes/article/view/119171.

Van Beuningen, C., De Jong, N. H. \& Kuiken, F. (2012). Evidence on the effectiveness of comprehensive error correction in Dutch multilingual classrooms. Language Learning, 62, 1-41. https://onlinelibrary.wiley.com/doi/abs/10.1111/j.1467-9922.2011.00674.x

Vygotsky, L. S. (1987). Thinking and speech. In R. W. Rieber \& A. S. Carton (eds.)., The collected works of L. S. Vygotsky. Vol. 1. Problems of general psychology (pp. 39-285). New York: Plenum.

Woolfolk, A. E., Winne, P. H., \& Perry, N. E. (2003). Educational psychology (2th ed.). Pearson Education Canada Inc: Allyn\& Bacon, Inc Needham Height, MA.

Yokota, D. \& ljuin, F. (2009). A Trial of Teaching Text Expression at the Beginner's Level Based on" JLC Japanese Standards. Tokyo University of Foreign Studies, Japanese Language Education Center, No.35

Yoshida, R. (2008). Teachers' choice and learners' preference of corrective feedback types. Language Awareness, 17(1), 78-93. https://www.tandfonline.com/doi/full/10.2167/la429.0.

Ziafar M., \& Namaziandost, E. (2019). Linguistics, SLA and lexicon as the unit of language. International Journal of Linguistics, Literature and Translation (IJLLT), 2(5), 245-250. https://alkindipublisher.com/index.php/ijllt/article/view/597. 